\title{
ALLOMETRY OF REPRODUCTION IN BROAD-SNOUTED CAIMAN (Caiman latirostris)
}

\author{
VERDADE, L. M. \\ Laboratório de Ecologia Animal, ESALQ, Universidade de São Paulo \\ Correspondence to: Luciano M. Verdade, Laboratório de Ecologia Animal, ESALQ, USP, C.P. 09, \\ CEP 13418-900, Piracicaba, SP, Brazil, e-mail: 1mv@carpa.ciagri.usp.br \\ Received March 4, 1999 - Accepted August 3, 2000 - Distributed August 31, 2001
}

(With 1 figure)

\begin{abstract}
In the present study regression equations are established between broad-snouted caiman (Caiman latirostris) captive reproductive females snout-vent length (SVL) and body mass (BM) and the following clutch characteristics: egg mass, egg "length" (maximal diameter), egg "width" (minimal diameter), hatchling BM, hatchling SVL, clutch size (number of eggs), clutch mass and relative clutch mass (clutch mass/ female BM). Female body-length presented a positive correlation with egg mass, egg length, egg width, hatchling BM and hatchling SVL. No clear correlation was found between female SVL and clutch size. Female BM showed a significantly positive correlation with egg mass, egg-length, egg-width, hatchling $\mathrm{BM}$, hatchling SVL and clutch mass. A highly significant negative correlation was found between female $\mathrm{BM}$ and the relative clutch mass. No clear correlation was found between female BM and clutch size.
\end{abstract}

Key words: allometric relations, reproductive biology, broad-snouted caiman, Caiman latirostris.

\section{RESUMO}

\section{Alometria reprodutiva em jacarés-de-papo-amarelo (Caiman latirostris)}

No presente estudo são estabelecidas equações de regressão entre comprimento e massa corpórea de fêmeas reprodutivas cativas de jacarés-de-papo-amarelo (Caiman latirostris) e as seguintes características relativas às ninhadas: massa, comprimento (isto é, diâmetro máximo) e largura (isto é, diâmetro mínimo) do ovo; massa e comprimento corpóreos dos filhotes; número de ovos, massa total e massa relativa da ninhada (isto é, massa total da ninhada/massa corpórea da fêmea). O comprimento corpóreo das fêmeas apresentou correlação positiva com a massa, o comprimento e a largura dos ovos e com a massa e o comprimento corpóreos dos filhotes. Não houve correlação entre o comprimento corpóreo da fêmea e o número de ovos da ninhada. A massa corpórea das fêmeas apresentou correlação positiva com a massa, o comprimento e a largura dos ovos e com a massa e o comprimento corpóreos dos filhotes. Uma correlação altamente significativa foi encontrada entre a massa corpórea das fêmeas e a massa relativa das ninhadas. Entretanto, não houve correlação entre a massa corpórea das fêmeas e o número de ovos da ninhada.

Palavras-chave: relações alométricas, biologia reprodutiva, jacarés-de-papo-amarelo, Caiman latirostris.

\section{INTRODUCTION}

Few studies about allometry of reproduction have been developed with crocodilians. Ferguson (1985) presents an extensive review about reproductive biology and embryology of crocodilians, with information about size at sexual maturity, clutch size, eggs' dimensions, and biometry of hatchlings for most species. Ferguson's review presents a great amount of information about interspecific variation on reproductive biology; however, little is presented about intraspecific variation. In addition, since he depended on literature he had no control on sample size, which for some of the species resulted in a single anecdotal report.

Hall (1991) used morphometric data from nesting Alligator mississippiensis and Crocodylus novaeguineae and associated clutch characteristics 
to produce regression models where demographic profiles of the reproductive females could be reliably estimated on the basis of clutch mass or clutch size. He found consistent allometric relations between female body mass and length and clutch mass and size.

In his study, Hall proposed the study of allometry of reproduction at the population level, in order to determine which segments or size-classes of females are actively breeding. This seems to be the best approach for large populations, such as the A. mississippiensis and C. novaeguineae. However, small populations may (and in some circumstances have to) be approached at the individual level. In small fragments of habitat, the "whole segment of reproductive females" may be just one or a few animals. In this case, allometric relations, such as the ones described by Hall may possibly be useful to identify reproductive individuals.

Thorbjarnarson (1996) reviews the reproductive characteristics of crocodilians and presents information on female size, egg mass, clutch size and mass, and some inter and intraspecific allometric trends. He reports that egg size, clutch size, and clutch mass are positively correlated with female body size at the interspecific level. According to him, intraspecific comparisons were limited by sample size, but among six species for which data were available, a positive correlation between female size and egg mass was found in all but Caiman latirostris. Thobjarnarson also reports a significantly positive relationship between clutch mass and female length, but once again $C$. latirostris was an exception. Unfortunately, Thorbjarnarson does not cite his information sources concerning the broadsnouted caiman, which could be useful to clarify these unusual patterns.

\section{MATERIAL AND METHODS}

In the present study regression equations are established between reproductive female snout-vent length (SVL) and body mass (BM) and the following clutch characteristics: egg mass, egg "length" (maximal diameter), egg "width" (minimal diameter), hatchling BM, hatchling SVL, clutch size (number of eggs), clutch mass and relative clutch mass (clutch mass/female BM). Relative clutch mass was determined by the ratio between clutch mass and the female BM prior to reproduction. Data from eight clutches from the captive breeding program of the broad-snouted caiman at the University of São Paulo, Piracicaba, Brazil were collected during the reproductive period of 1995/1996, with the exception of two nests from former years. Reproductive females were weighted and measured in early October. At this period of the year, females usually show a small to medium development of follicles (Vac et al., 1992). Egg-laying occurs in São Paulo from November to February, with peak in January (Verdade, 1995). Least-square regression equations are presented in Table 1. Their plots are presented in Fig. 1. Statistical analyses were done in Minitab for Windows 11 (Minitab, 1996). Their procedures are presented in Table 1.

\section{RESULTS AND DISCUSSION}

Contrary to the pattern described by Thorbjarnarson for broad-snouted caiman, in the present study a positive correlation was found between egg mass and female SVL $\left(r^{2}=0.699\right.$, P-value < 0.000). A positive correlation, although not so significant, was found between clutch mass and female SVL $\left(r^{2}=\right.$ 0.406 , P-value $=0.082$ ). Female SVL showed also a significant positive correlation with egg length $\left(r^{2}=0.548, P\right.$-value < 0.000), egg width $\left(r^{2}=0.678\right.$, $\mathrm{P}$-value $<0.000)$, hatchling BM $\left(\mathrm{r}^{2}=0.627\right.$, P-value < $0.000)$, and hatchling SVL $\left(r^{2}=0.619, \mathrm{P}\right.$-value < $0.000)$. No clear correlation was found between female SVL and clutch size $\left(r^{2}=0.414\right.$, P-value = 0.297). A negative correlation, although not highly significant, was found between female SVL and the relative clutch mass $\left(r^{2}=0.594, \mathrm{P}\right.$-value $\left.<0.065\right)$.

Female BM showed a significantly positive correlation with egg mass $\left(\mathrm{r}^{2}=0.693\right.$, P-value < $0.000)$, egg-length $\left(r^{2}=0.548\right.$, P-value $\left.<0.000\right)$, eggwidth $\left(\mathrm{r}^{2}=0.582\right.$, P-value $\left.<0.000\right)$ hatchling BM $\left(\mathrm{r}^{2}=\right.$ 0.630 , P-value < 0.000), hatchling SVL $\left(r^{2}=0.578\right.$, $\mathrm{P}$-value $<0.000)$ and clutch mass $\left(\mathrm{r}^{2}=0.615, \mathrm{P}-\right.$ value $<0.021)$. No clear correlation was found between female BM and clutch size $\left(r^{2}=0.354\right.$, Pvalue $=0.120$ ). A highly significant negative correlation was found between female BM and the relative clutch mass $\left(\mathrm{r}^{2}=0.755, \mathrm{P}\right.$-value $\left.<0.005\right)$.

With the exception of clutch size, there is a clear positive correlation between female body-size (in its turn correlated with BM or SVL) and all studied clutch characteristics, from the egg size to the hatchling body-size. 

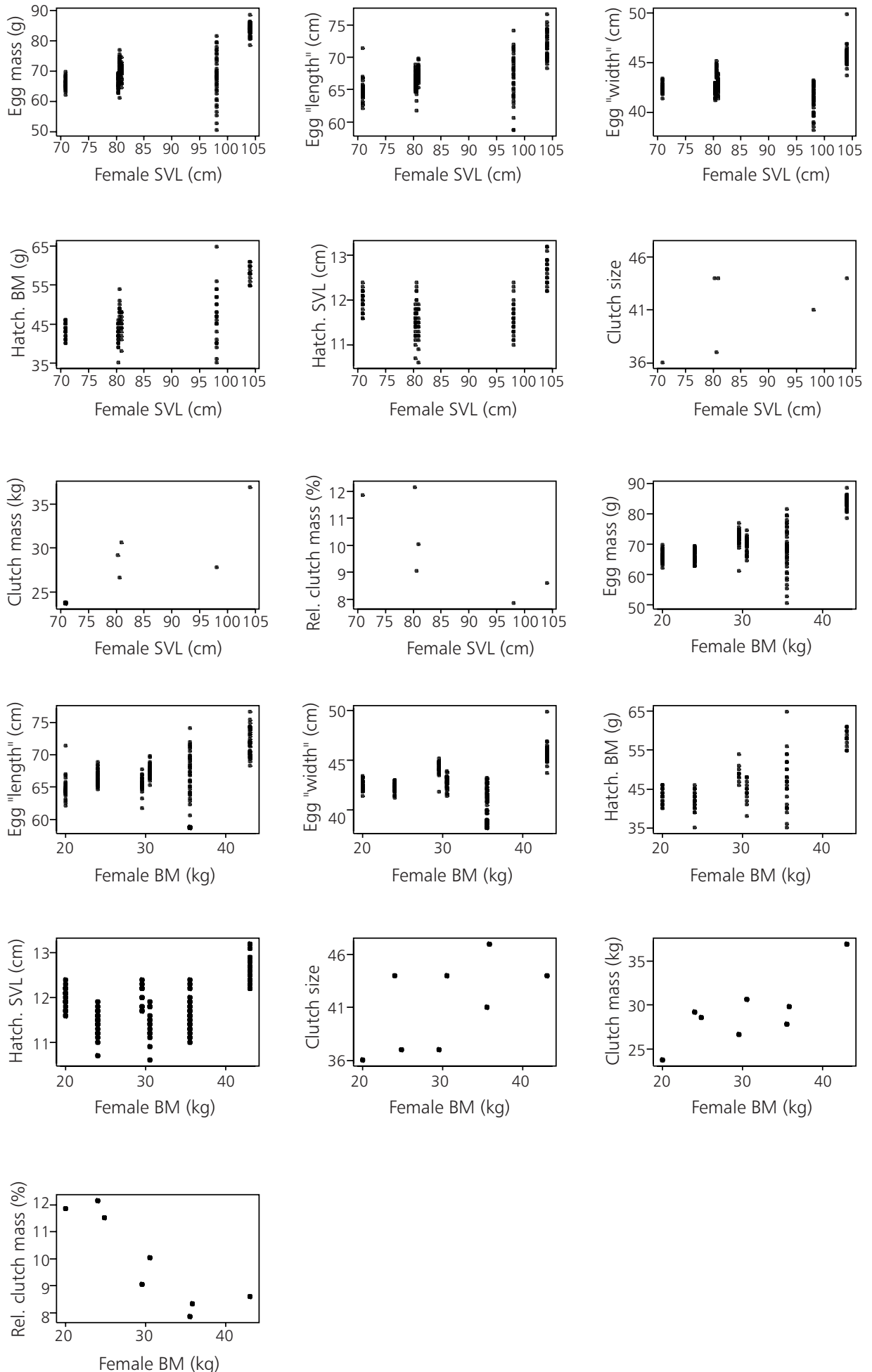

Fig. 1 - Plots of regression equations between reproductive females body-size and clutch characteristics allometric relations of reproduction. See Table 1 for regression equations. Relative clutch mass $(\%)=$ clutch mass $(\mathrm{kg}) / \mathrm{female}$ body mass $(\mathrm{kg})$. 
TABLE 1

Allometry of reproduction: least-square regressions.

\begin{tabular}{|c|c|c|c|c|c|c|c|c|c|}
\hline N. & $\mathbf{Y}$ & $\mathbf{X}$ & $\mathbf{a}$ & $\mathbf{b}$ & c & d & P-value & $\mathbf{r}^{2}$ & $\mathbf{N}$ \\
\hline 1 & Egg mass (g) & $\begin{array}{l}\text { Female } \\
\text { SVL }(\mathrm{cm})\end{array}$ & -2211.89 & 82.3432 & -0.9841 & 0.0039 & 0.000 & 0.699 & 198 \\
\hline 2 & Egg "length" (cm) & $\begin{array}{l}\text { Female } \\
\text { SVL }(\mathrm{cm})\end{array}$ & -64.6826 & 2.55316 & -0.0303 & 0.0001 & 0.000 & 0.548 & 198 \\
\hline 3 & Egg “width” (cm) & $\begin{array}{l}\text { Female } \\
\text { SVL (cm) }\end{array}$ & -70.3161 & 2.69749 & -0.0322 & 0.0001 & 0.000 & 0.678 & 198 \\
\hline 4 & Hatchling BM (g) & $\begin{array}{l}\text { Female } \\
\text { SVL }(\mathrm{cm})\end{array}$ & -1196.7 & 45.5406 & -0.5536 & 0.0022 & 0.000 & 0.627 & 124 \\
\hline 5 & Hatchling SVL (cm) & $\begin{array}{l}\text { Female } \\
\text { SVL }(\mathrm{cm})\end{array}$ & -67.8018 & 3.1135 & -0.0399 & 0.0002 & 0.000 & 0.619 & 124 \\
\hline 6 & Clutch size & $\begin{array}{l}\text { Female } \\
\text { SVL }(\mathrm{cm})\end{array}$ & 28.002 & 0.1515 & & & 0.297 & 0.414 & 8 \\
\hline 7 & Clutch mass (kg) & $\begin{array}{l}\text { Female } \\
\text { SVL }(\mathrm{cm})\end{array}$ & 0.063 & 0.027 & & & 0.082 & 0.406 & 8 \\
\hline 8 & Relative clutch mass & $\begin{array}{l}\text { Female } \\
\text { SVL }(\mathrm{cm})\end{array}$ & 0.1947 & 0.0011 & & & 0.065 & 0.594 & 8 \\
\hline 9 & Egg mass (g) & $\begin{array}{l}\text { Female } \\
\mathrm{BM}(\mathrm{kg})\end{array}$ & -96.6885 & 17.2127 & -0.5908 & 0.0067 & 0.000 & 0.693 & 198 \\
\hline 10 & Egg "length" (cm) & $\begin{array}{l}\text { Female } \\
\text { BM }(\mathrm{kg})\end{array}$ & 1.0757 & 0.5725 & -0.0195 & 0.0002 & 0.000 & 0.548 & 198 \\
\hline 11 & Egg “width” (cm) & $\begin{array}{l}\text { Female } \\
\text { BM }(\mathrm{kg})\end{array}$ & -2.3833 & 0.7046 & -0.0241 & 0.0003 & 0.000 & 0.582 & 198 \\
\hline 12 & Hatchling BM (g) & $\begin{array}{l}\text { Female } \\
\text { BM }(\mathrm{kg})\end{array}$ & 66.368 & -1.9687 & 0.0410 & & 0.000 & 0.630 & 124 \\
\hline 13 & Hatchling SVL (cm) & $\begin{array}{l}\text { Female } \\
\text { BM (kg) }\end{array}$ & 16.5978 & -0.3566 & 0.0061 & & 0.000 & 0.578 & 124 \\
\hline 14 & Clutch size & $\begin{array}{l}\text { Female } \\
\text { BM }(\mathrm{kg})\end{array}$ & 31.3067 & 0.3272 & & & 0.120 & 0.354 & 8 \\
\hline 15 & Clutch mass (kg) & $\begin{array}{l}\text { Female } \\
\text { BM }(\mathrm{kg})\end{array}$ & 1.7183 & 0.0395 & & & 0.021 & 0.615 & 8 \\
\hline 16 & Relative clutch mass & $\begin{array}{l}\text { Female } \\
\text { BM }(\mathrm{kg})\end{array}$ & 0.16 & -0.002 & & & 0.005 & 0.755 & 8 \\
\hline
\end{tabular}

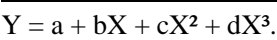

Relative clutch mass: clutch mass $(\mathrm{kg}) /$ female BM $(\mathrm{kg})$.

Minitab procedure: stat $\rightarrow$ regression $\rightarrow$ regression (response: Y; predictors: $\mathrm{X}$ ).

In other words, larger females tend to produce heavier (instead of more numerous) offspring. However, there seems to be a relatively minor physiological cost as females grow. In the present study for a $20 \mathrm{~kg}$ female clutch mass represents approximately $12 \%$ of her own body-mass, whereas for a $40 \mathrm{~kg}$ female, clutch mass represents only approximately $8 \%$. Not surprisingly, the (negative) correlation between female BM and clutch mass is the most significant allometric relation found in this study $\left(\mathrm{r}^{2}=0.755\right)$.

From the physical constraints suffered by the eggs during incubation to the winter weather con- ditions faced by hatchlings soon after hatching, there must be a great number of distinct selective pressures (see Campos, 1993 and Imhof et al., 1996, for the effect of habitat on the survival of eggs). Although broad-snouted caiman's clutch size range varies approximately 2.72 times from the smallest to the most numerous (18-49 eggs, according to Verdade et al., 1992; approximately the same according to Larriera, 1991), there must be a selective pressure strong enough to prevent the viability of smaller clutches.

Hatchling body size may be related to survival rate at the first winter, mainly in the southern- 
most part of the distribution of the species (Piña et al., 1996). This differential success may benefit larger females. It is tempting to believe that this happens in well established populations with "healthy" structured age-pyramids and a well established hierarchy among reproductive individuals. However, this may not be the case of small populations inhabiting fragmented and anthropogenic landscapes on a metapopulation context, in which social structure and behavioral ecology may be completely altered (Hanski \& Gilpin, 1997). The possible consequences for the conservation of the species under such circumstances are unknown.

Although the allometric relations above are statistically significant, the high variation found (see Fig. 1) prevents their use in the assessment of individual parents from clutch characteristics as suggested by Hall (1991), even in small populations. Multivariate statistical analyses seem to be more appropriate to accomplish this goal (Verdade, 1997).

Acknowledgments - This study is a part of the dissertation presented to the Graduate School of the University of Florida in partial fulfillment of the requirements for the degree of Doctor of Philosophy. This program was supported by the Conselho Nacional de Desenvolvimento Científico e Tecnológico - CNPq (Process n. 200153/93-5) and the University of São Paulo, Brazil. I am thankful to Prof. F. Wayne King, J. Perran Ross, Lou Guillette, Richard Bodmer, Mel Sunquist, George Tanner, Phil Hall and Irineu U. Packer for their ideas and comments on the manuscript. Edson Davanzo, Fabianna Sarkis, Ana Maria V. Castro, and Dennis L. Sinisgalli helped to measure the animals.

\section{REFERENCES}

CAMPOS, Z., 1993, Effect of habitat on survival of eggs and sex ratio of hatchlings of Caiman crocodilus yacare in the Pantanal, Brazil. Journal of Herpetology, 27(2): $127-132$

FERGUSON, M. W. J., 1985, Reproductive biology and embryology of the crocodilians. pp. 329-492. In: C. Gans, F. Billett \& P. F. A. Maderson (eds.), Biology of the Reptilia. Vol. 14. Development A. John Wiley \& Sons, New York.

HALL, P. M., 1991, Estimation of nesting female crocodilian size from clutch characteristics: correlates of reproductive mode and harvest implications. Journal Herpetology, 25(2): 133-141.

HANSKI, I. A. \& GILPIN, M. E. (eds.), 1997, Metapopulation Biology: Ecology, Genetics, and Evolution. Academic Press, San Diego.
IMHOF, A., COSTA, A. \& LARRIERA, A., 1996, The environment and its relationship with egg size, clutch size and hatchling success in different Caiman latirostris populations at Santa Fe, Argentina. pp. 249253. In: Crocodiles. Proceedings of the $13^{\text {th }}$ Working Meeting of the Crocodile Specialist Group. IUCN The World Conservation Union, Gland, Switzerland.

LARRIERA, A., 1991, Clutch size and hatching success in broad-snouted caiman, Caiman latirostris (Crocodylia: Alligatorinae) in Santa $\mathrm{Fe}$ Province, Argentina. Rev. Asoc. Cienc. Nat. Litoral, 22(1): 1923.

MINITAB, 1996, Minitab for Windows Release 11. Minitab, Inc., State College, PA, U.S.A.

PIÑA, C., IMHOF, A. \& SIROSKY, P., 1996, Egg size of Caiman latirostris and its relationship with clutch size, hatching success, survival and growth. pp. 254-260. In: Crocodiles. Proceedings of $13^{\text {th }}$ Working Meeting of the Crocodile Specialist Group IUCN - The World Conservation Union, Gland, Switzerland.

THORBJARNARSON, J. B., 1996, Reproductive characteristics of the Order Crocodylia. Herpetologica, 52(1): 8-24.

VAC, M. H., VERDADE, L. M., MEIRELLES, C. F., LARSEN, R. E., MICHELOTTI, F., RANGEL, M. C., SALEM, C. Z. \& LAVORENTI, A., 1992, Ultrasound evaluation of the follicle development in adult female broad-nosed caiman (Caiman latirostris). pp. 176-183. In: Crocodiles. Proceedings of the $11^{\text {th }}$ Working Meeting of the Crocodile Specialist Group. IUCN - The World Conservation Union, Gland, Switzerland.

VERDADE, L. M., 1995, Biologia reprodutiva do jacaréde-papo-amarelo (Caiman latirostris) em São Paulo, Brasil. pp. 57-79. In: A. Larriera \& L. M. Verdade (eds.), Conservación y Manejo de los Crocodylia de America Latina. Vol. 1. Fundación Banco Bica, Santo Tomé, Santa Fe, Argentina.

VERDADE, L. M., 1997, Morphometric Analysis of the broad-snouted Caiman (Caiman latirostris): an assessment of individual's clutch, body size, sex, age, and area of origin. Ph.D. Dissertation, University of Florida, Gainesville, Florida, USA, 174p.

VERDADE, L. M., LAVORENTI, A., MICHELOTTI, F., RANGEL, M. C., CULLEN Jr. L. \& ERNANDES, M. M., 1992, Preliminary notes on nesting biology of the broad-snouted caiman (Caiman latirostris) in São Paulo, Brazil. pp. 226-232. In: Crocodiles. Proceedings of the $11^{\text {th }}$ Working Meeting of the Crocodile Specialist Group IUCN - The World Conservation Union, Gland, Switzerland. 